\title{
Offerings and the Production of Buddhist Scriptures in Dunhuang during the Tenth Century
}

HENRIK H. SØRENSEN

ERC Project BuddhistRoad, CERES, Rubr-Universität Bochum benrik.soerensen@rub.de

Abstract: This study explores the production of Buddhist scriptures in Dunhuang during the late medieval period, with a focus on the period when Hexi was ruled by the Guiyijun 歸義軍 regime from 848 to c. $1038 \mathrm{CE}$. The study is divided into five parts which deal with the historical background and the nature of the sources, typologies of scriptural production as an integral part of Buddhist offerings, official donations of Buddhist scriptures in Dunhuang, privately produced scriptures as offerings, and finally, a case study regarding the celebrated lay-Buddhist and scholar Zhai Fengda's copy of the Vajracheedikā.

Keywords: Scriptural production, Dunhuang, offerings, donations, Guiyijun, Buddhist scriptures, Zhai Fengda

DOI: https://dx.doi.org/10.15239/hijbs.03.01.03 


\section{Introduction}

There are numerous ways to approach the celebrated cache of 1 manuscripts from cave no. 17 in the Mogao Caves 莫高窟 at Dunhuang 敦煌, and indeed a number of such have been explored since the study of this rich and intriguing material began more than a full century ago. Given that the bulk of said material pertains to Buddhism and Buddhist scriptures, combined with the fact that donor colophons and other data throw light on how they were producedand how this production further informs us regarding beliefs and practices surrounding it-we are now in a fairly good position to formulate relatively precise overviews as well as access more in-depth information.

In this paper I shall be looking at the production and copying of Buddhist scriptures in Dunhuang during the late medieval period as part of donations, with the purpose of understanding who their initiators or agents were, how they conceived of the projects they undertook, and on what occasions, for what reasons, and what the concrete outcomes of this were. I shall base my findings on a series of case-studies, all of which pertain to scriptural production, including examples that reflect on both the diversity typologically as well the social backgrounds of the agents involved. I hope that such an approach shall inform us in the greatest possible detail how Buddhist scriptures were produced locally on the eve of what was perhaps the single-most significant event in Chinese Buddhist history, namely the printing of the first officially sanctioned canon, the Kaibao Tripitaka 開寶大藏經 in Sichuan in 982 CE.

I do not intend to discuss the situation of the Buddhist libraries in Dunhuang here, as I am primarily interested in scriptural production from the perspective of donations, i.e. as offerings. Even so, further knowledge of how the temple libraries and their scriptoria functioned will be a most welcome addition to our current knowledge.

Given the great number of primary sources in Chinese on Buddhism in Dunhuang available to us today, I have limited my field of investigation to the production and re-production of canonical sütras and apocryphal scriptures, i.e. works with sütra-status written 
or composed in China. ${ }^{1}$ It goes without saying that this material only covers a fraction of the sources in Chinese- not to forget those written in other languages-thus leaving the discussion of other Buddhist texts typologies such as treatises (lun 論), transformation texts (bianwen 變文), lecture texts (jiangwen 講文), ritual works, and poetry, including local compositions, for others to deal with.

\section{The Historical Background and the Nature of the Sources}

Dunhuang during the tenth century is characterised by the lengthy period when the Guiyijun 歸義軍 regime-especially that of the Cao clan 曹氏一ruled over the area known at that time as Hexi 河 西, but which was essentially a relatively small territory comprising the prefectures of Shazhou 沙州 and Guazhou 瓜州. ${ }^{2}$ The primary sources from this period found among the Dunhuang manuscripts offer us an abundance of detailed information on how practices surrounding the production of Buddhist scriptures played out, and for that very reason I shall mainly be dealing with this material in the following discussion. As pious Buddhists, the Cao, as well as the other prominent clans in Shazhou, Dunhuang's principal seat of government, undertook numerous activities for the sake of Buddhism, both for pious reasons as well as for self-promotion. Many of the pious works they initiated and carried out involved the up-keep of Buddhist institutions, the excavation of new votive caves, the repair and maintenance of old ones, replacement of religious paraphernalia, including votive paintings, and last but not least, providing donations of holy scriptures to the libraries of the temples. While we

1 For more on this, see Liu, 'Dunhuang xiejuan zhongtu zao jing de jiushu sixiang tiyao'. See also Fang, ed., Fojiao wenxian yanjiu. This compilation features the most recent work primarily by Mainland scholars on apocryphal Buddhist scriptures.

2 There are several important studies discussing the situation in Dunhuang during the reign of the Guiyijun. Even so, the best overview is still Rong, Guiyijun shi yanjiu. 
may surmise that such donations made up the bulk of scriptures that entered into the monastic library-holdings-what one could refer to as official donations - the donations of scriptures given or organised on an individual basis were equally significant. A famous example of this is the Buddhist monk Daozhen's 道真 (c. 915-987) decade long attempt at amending the library of his monastic home, the Sanjie Temple 三界寺. ${ }^{3}$

The primary sources when dealing with the production and donations of Buddhist scriptures in Dunhuang are, of course, the manuscripts from cave no. 17. Many scriptures found here were made specifically for the purpose of donation and often feature colophons with their makers' dedications. In these dedicatory texts donors express their motives for having a given scripture copied. These dedications or statements concerning scriptural production serve a number of purposes. First of all, they indicate the reasons and circumstances behind the copying. Secondly, they often, but not always, bear statements concerning the practice of merit transference. Thirdly, they function as a sort of self-presentation, in which the pious act is being communicated to whoever comes into contact with the copied book. The latter motive may thus be understood as a mainly social function, but one which nevertheless underscores the donor's religious status. We can also see this in the closely related act of offering votive paintings, in which portraits of the donor as well members of his or her families are often included. In some cases the donor-portraits take up as much space in a given painting as the main icon itself. ${ }^{4}$ It would appear that self-promotion, as well as the kind of self-presentation we see in the growing importance of including

3 Daozhen's attempt at restoring the library holdings of his temple has been discussed in Rong, Eighteen Lectures on Dunbuang, 79-108. For a more detailed study of Daozhen and his activities, see Sørensen, 'The Life and Times of Daozhen'.

4 A compilation of these donor inscriptions have been collected and commented upon in Ma, 'Dunhuang juanhua tiji jilu'. A more recent study is Soymié, 'Les donateurs dans les peintures de Dunhuang'. See also Sørensen, 'Donors and Image at Dunhuang'. 
portraits in religious paintings in Dunhuang, reflects a new trend wherein the performance and documentation of 'good deeds' took on a more public function in society. This also becomes evident when compared with earlier donor-portraits from the Tang dynasty, which appear relatively small and modest in comparison with those of the Five Dynasties period and the early Northern Song.

\section{Typologies of Scriptural Production as Part of Buddhist Offerings}

Having presented a historical overview of the situation in Dunhuang during the tenth century in regard to scripture-production, let us now turn to the actual cases to see what information they may offer. However, before doing so, let us dwell briefly on the issue of categories and typologies in the creation of Buddhist scriptures. It is quite easy, even self-evident, to observe in the surviving documents that the production of holy books happened on many levels and in a variety of ways. Therefore, we may distinguish between at least two major categories of such donations, namely official and private.

'Official' indicates donations made by the Guiyijun government as part of a formal legitimation strategy whereby it worked in symbiosis with local Buddhism, as both protector and the protected. While the government supported Buddhism, it was at the same time in a position to harness the religion for its own specific purposes. Furthermore, during the tenth century, many of the leading Buddhist monks and temple-officials hailed from important local clans, which meant that the ruling class and the formal make-up of local Buddhist power-structures were completely integrated on a functional level. We should also keep in mind that by supporting Buddhism, the government was nurturing an important economic generator in so far as Buddhism brought significant revenue to the area through its important sanctuaries.

'Private donations' signal those made by individuals or family-based donations. Of course, a private donation could also be made for pious reasons by a member of the government, and indeed they were. However, in those cases we may conceptualise this type of donation 
as 'both and' cases, i.e. as donations which, while they may have been motivated by personal religious sentiments, at the same time played into local legitimation and power. This is also why private donations made by members of the ruling Cao clan were often lavish and on a grander scale than those made by the commoners. For instance, we see a marked difference between, on the one hand, the quality and intent of votive paintings donated by the Cao and other nobility, and those made by the much larger group of common lay-Buddhists in Dunhuang. ${ }^{5}$

While donor colophons attached to books, whether printed ones or manuscripts, tend to reflect individualised concerns, in many cases they were made by rulers or members of the local elite, who thereby signal their acts of piety in a manner that went well beyond the more narrow, personalised motives of ordinary Buddhist believers. This is because a member of the political and social elite in a given locale made their donations or offerings not only as individuals, but as leading members of society, namely as persons of significance. As someone belonging to a specific and noteworthy group at the top of the social hierarchy, norms including codes of behaviour were dispensed to the larger community in a hegemonic manner. Therefore, as soon as such events of donation became 'public' in the sense that they displayed a specific ordered system of power and status, they tended to take on a more distinctly official character.

Clearly stated motives for making scriptural donations vary considerably in our sources, and these motives are of course most notable in cases of private donations, where colophons often provide us with an insight into the sentiments of the donor. It is beyond the scope of this essay to go into detail with these motives, a study in its own, wherefore I shall limit myself to providing a listing of the most evident concerns, which are as follows:

- Repose and bliss for deceased parents and ancestors

- Healing of self and others

- Blessings for the ruler and the territory

5 Sørensen, 'Donors and Esoteric Buddhism in Dunhuang'. 
- Blessings for society at large

- Blessings for self (religious merit)

- Ascend to the Pure Land for self and others

- Avoidance of descent into the hells

- Getting rid of suffering

- Being protected from harm

- Seeking longevity

- Harmony in the family

While this list of motives covers many aspects of Buddhist life, it is clear that those relating to mortuary practices and beliefs tend to dominate the sources. In other words, scriptural donations were in many cases directly concerned with the creation and transference of merit on behalf of a deceased family member.

Shifting the discussion to the Buddhist institutions in Dunhuang, it goes without saying that the production and copying of Buddhist scriptures were primary activities for the monasteries in Dunhuang, both for own use but also for paying customers, and that most of the concerted efforts to replenish and amend their libraries were taken care of by the monastics themselves. The Dunhuang manuscripts provide us with numerous examples of individual or groups of monks concerned with scriptural production, but in any case we should expect that during the period of manuscripts, i.e. before entire sets of the Tripitaka were available in printed form, the writing and copying of manuscripts was a major activity of the Buddhist institutions. ${ }^{6}$ As monastic production of Buddhist scriptures in

6 For a highly useful compilation and annotation of the library holdings and related records from the temples in Dunhuang, see Fang, ed., Dunbuang fojiao jinglu jixiao. See also Fang, Zhongguo xieben Dazang jing yanjiu; and Fang, 'Dunhuang siyuan suo zang dazang jing gaimao'. Fang presents many arguments in favour of the existence of a complete Tripitaka in Dunhuang during the late Tang and Five Dynasties period. I remain unconvinced that there were complete sets comparable to the listing in the celebrated Kaiyuan Catalogue, ( $T$ no. 2154, 55), even though we do know that some of the Tang catalogues were indeed available there. 
Dunhuang is a topic unto itself, I shall not dwell on this at length here, but limit myself to providing a few illustrative examples of how this took place.

In $964 \mathrm{CE}$, various monks including the monk-controller (sengzheng 僧政), together with the librarian (sijing 司經), Huiyan 惠宴 (fl. second half of tenth century) hailing from an unnamed temple, revised the scriptures in their library and found that many were without their wrappers and were in a general state of disarray. We must surmise that the idea behind this survey was to reorganise the collection. At that time, the monk Haiquan 海詮 (fl. second half of tenth century) requested that a copy of the abbreviated Pseudo-Śurangama Spell (Da foding lüe zhou 大佛頂略咒 $)^{7}$ to be added to the collection, while the monk Huici 惠慈 (fl. second half of the tenth century) requested that two rolls of the Suvarnaprabhassa-sūtra ${ }^{8}$ be entered as well. ${ }^{9}$ We can imagine that activities of this kind were commonplace, and that the keeping of order in these medieval manuscript collections required a great deal of sustained effort. It was of course on such occasions that old scriptures were repaired and missing parts of sets of rolls were amended with new copies. As such this case is largely similar to that which led the celebrated Daozhen to amend the library at Sanjie Temple as briefly mentioned above.

\section{Official Donations of Buddhist Scriptures in Dunhuang}

When compared with the great number of privately donated Buddhist scriptures, those large-scale, government-sponsored sets of sütras bestowed upon select monasteries were, in contrast, relatively

7 The exact spell intended here is uncertain, but I presume that the reference is to this spell, i.e. that of the Shoulengyan jing 首楞嚴經 (Pseudo-ŚurangamaSütra), $T$ no. 944A, 19 or $T$ no. 944B, 19, of which several copies have been found among the Dunhuang manuscripts. Cf. eg. S. 1326, S. 2326, S. 3782, S. 4359, Beijing 7417, etc.

$8 T$ no. 665, 16.

9 S. 2142. 
few and far between. One notable exception to this was the scriptural donation in 966 by Cao Yancheng 曹延晟 (fl. mid-to late tenth century), a son of the important Guiyijun ruler Cao Yuanzhong 曹 元忠 (r. 944-974). It is recorded that Yancheng had the Mahäprajūāpramitā-sūtra ${ }^{10}$ copied and donated to the local Xiande Temple 顯德寺. ${ }^{11}$

Another case of an official donation, in this case of a single, short sütra, is the carving and printing of the Vajracheedika by Cao Yuanzhong in $949 \mathrm{CE} .{ }^{12}$ The colophon accompanying this printing is terse and includes few emotional or formalistically pious outbursts. It simply reads:

The disciple, Guiyjun Governor and Emissary, Censor, Grand Tutor Conjointly [of the Compilation of] the Imperial History, Great Person and Duke Establishing the Nation, Cao Yuanzhong widely bestows [this scripture] for upholding. Recorded on the 15th day in the 5th month of the 15th yiyou year of the Tianfu [reign-period] (i.e. 949 CE). The printing block carved by Lei Yanmei 雷延[美] (fl. mid-10th cent.). ${ }^{13}$

The official nature of this donation of a Buddhist scripture is further underscored by the fact that the printed copies of the Vajracheedik $\bar{a}$ were meant for wide distribution among the faithful. ${ }^{14}$ In other words, the event represents a public gesture of generosity, pious or otherwise, from the local ruler and extended to the Buddhists of Dunhuang. Nowhere does Cao Yuanzhong mention any personal

10 Tno. 220, 4.

11 Beijing 1429. See Zheng, 'Wan Tang Wudai Dunhuang diqu Dabanruo jing'.

12 Further information on the development of printing as evidenced in the Dunhuang material may be had from Barrett, 'Transcribed Printers'.

13 P. 4514: 弟子, 歸義軍節度使, 特進檢校, 太傅兼御史, 大夫譙郡開國侯, 曹 元忠普施受持. 天福十五年己酉歲五月十五日記. 雕板押衙 雷延美.

14 For additional information of the use and circulation of this scripture, see Fang, 'Dunhuang wenxian de zhong Jingang jing'. 
wishes or prayers in connection with his act of donation, and it is only through the fact that he declares himself 'a disciple', i.e. a Buddhist, that we may glimpse a religious motive behind the event.

We also find that production and transmission of Buddhist scriptures took place as a part of diplomatic gifts and exchange of goods. In $942 \mathrm{CE}$ when receiving a legate from Khotan on his way to the court of the Later Jin 後晉 (936-946) at Shazhou, local monks recited prayers for three days at the behest of Cao Yuanshen. ${ }^{15} \mathrm{On}$ that occasion, Khotanese texts, including an outline of the Saddharmapundarika (Fabua jing gangyao 法華經綱要), ${ }^{16}$ as well as texts featuring dhāranīs (Ch. tuoluoni zhou 陀羅尼呪), ${ }^{17}$ were presented at Dunhuang. ${ }^{18}$ Obviously these texts were nothing like formal scriptures for a Buddhist library, but more like pious presents given as tokens of religious sentiment.

On the Chinese side of such use of scriptural production, we can note an example in which the Guiyijun ruler Cao Yuanzhong and his wife worshipped at the Mogao Caves together with a Khotanese prince, who had arrived as a diplomatic emissary, and in the case of an Uyghur leader, most probably from the Ganzhou 甘州 Khagkanate, i.e. the Eastern Uyghur Kingdom. ${ }^{19}$ On that occasion, local monks were requested to copy out the Buddhanamas sütra. ${ }^{20}$ Afterwards, each of the sixteen major temples in Dunhuang received a set of the scripture. ${ }^{21}$

15 Cf. P. 4046.

16 This is not the actual title, but rather a description of what the text featured.

17 This may simply refer to the chanting of dhäranis and spells.

18 Examples of such texts are P. 2782, and P. 5535. The latter of these provides the name in Chinese of Liu Zaisheng 劉再昇, the Khotanese ambassador, whom Cao Yuanshen and Cao Yuanzhong accompanied to China.

19 Dunhuang yanjiuyuan, ed., Dunbuang Mogao ku gongyang ren tiji, 32.

20 T no. 441, 14.

21 Duan and Shi, eds., Gansu cang Dunbuang wenxian, 1: 207. 


\section{Privately Produced and Donated Scriptures}

When discussing private donations of scriptures, it is interesting to observe that there were no real differences between those made by the common lay-Buddhists and those by monastics. Not only are the motives largely the same (cf. the list above), there is also a great deal of overlap between the choice of scriptures copied on such occasions.

Despite being a member of the ruling Cao clan in Dunhuang, a donor could also make a scriptural offering in a strictly private capacity. One such example may be found in the lengthy colophon appended to an offering of an entire series of Buddhist scriptures:

On the 13th day of the 10th month of the 6th xinchou year of the Tianfu [reign-period], (i.e. $941 \mathrm{CE}$ ), the female disciple of pure faith, the young woman of the Cao family commissioned the copying of the Hrdāya-prajñāpāramitā sūtra ${ }^{22}$ in one roll, the Xuming jing 續命 經 [Scripture on the Extension of the Span of Life] ${ }^{23}$ in one roll, the Yan shouming jing 延壽命經一卷 [Scripture on Longevity and the Span of Life], ${ }^{24}$ and the Marīi $\overline{-}$ devi sutra ${ }^{25}$ in one roll, respectfully offered on behalf of herself, as she suffers from difficulties. Today she presents a number of scriptures [as offerings] since the medicine dumplings (yao'er 藥飭) ${ }^{26}$ that were bestowed again and again in

\footnotetext{
$22 T$ no. 251,8 .

$23 T$ no. 2889,85 .

$24 T$ no. 2888,85 .
}

25 Cf. T no. 1256,21 (P. 2805, P. 3136, P. 3824, etc.). Most of the copies of this scripture found among the Dunhuang hoard of manuscripts are short, abbreviated versions deriving from the translation by Amoghavajra. Cf. T no. 1255, 21.

26 These medicinal buns can be documented in the Chinese primary sources from the early Tang onwards. One early Buddhist case of their use can be found in Sengchou's 僧稠 (480-560) biography in the Xu Gaoseng zhuan 續高僧傳 (Continuation of the Histories of Famous Monks), $T$ no. 2060, 50: 16.554c4; and in Bodhiruci's monumental version of the Amoghapāsakalparāja. Cf. T no. 1092, 20: 18.324b6. They are also to be found in the celebrated materia mater, Qianjin yifang 千金醫方 [Medical Prescriptions Worth a Thousand Gold 
the morning, still has not made her well, and she now lies sick [in bed]. Beginning to realise her former misdeeds, she humbly begs the Great Holy Ones to relieve her hardships and lift her out of danger, and that the mirror (jian 鑒) ${ }^{27}$ will reflect the virtue of the copying of scriptures. She [therefore] hopes to be protected, and that this troublesome danger will be eliminated, that deceased family debtors (zhaizhu 債主 $)^{28}$ will receive their capital [when] the merit is divided, and that they will [subsequently] go for rebirth in the Western [Pure Land]. With a mind full of prayer she eternally supplies these as offerings on behalf of her deceased, former parents [so that they will be] well and healthy, and that everyone will in this realm ${ }^{29}$ [adhere to] the tradition (chuantong 傳統) of the path of filiality (xiaodao 孝道), and that more than anything extend to and include seven generations of former dead [in the family], benefiting them by using the copying [Buddhist] scriptures [as a means of] exhausting filial piety.

In the colophon appended to these copied scriptures is expressed the clearest and superior display of sincerity, which is [hereby] brought to the attention of society. ${ }^{30}$

From this text of dedication we learn that the Cao donor's primary motive is to recover from her sickness, and that since the medicinal dumplings have failed to effect a cure, she has resorted to the donation of holy scriptures. It is significant that she also prays that the enemies of her family will be appeased by the offering, and that they will attain rebirth in the Pure Land of Sukhāvatī as well. She also wishes for her deceased parents and former generations to be at ease.

Pieces] from $682 \mathrm{CE}$. For an easy-to-access version of the Qian jin yifang, see http://seirouoosone.web.fc2.com/SennkinnYokuhouHanntai.pdf, 417, 459, etc. (accessed April 3, 2018).

27 This undoubtedly refers to the Mirror of Karma in the Netherworld in which King Yāma can see the karmic deeds of those coming before him. For more on this see Sørensen, 'The Meeting of Daoist and Buddhist Spatial Imagination'.

28 I read this to refer to so-called unresolved karmic debts from the past.

29 I.e. being reborn again in the country.

30 P. 2805. 
Clearly, family issues play a dominant role in this dedication, something which surely reflects on the deep-seated adherence to and support of traditional Chinese cultural and ethical values. ${ }^{31}$ One can say that such a display of different forms of piety expressed here matches, in many ways, those we find in the colophons on religious paintings from Dunhuang. ${ }^{32}$ The scriptures copied as offerings on this occasion, i.e. the Hrdāya-prajñāpāramitā sütra, the Xuming jing, the Yanshou ming jing, and the Marici-devi sütra, are all short scriptures, and as such suitable for reproduction on a relatively short notice. It is noteworthy that of the four, half of them are apocrypha, a trend which appears to have been especially common in tenth century Dunhuang with regard to private offerings of Buddhist scriptures.

Another case of a scriptural offering, this time by a Buddhist nun, involves the copying of the Parināmacakra-sütra (Huixianglun jing 迴向輪經). ${ }^{33}$ It bears a short colophon the text of which reveals the following:

On the 16th day in the 1st month of an yichou year (965? CE) at Guazhou the nun Zhiqing 智清 (fl. mid-10th century) decided to have [this scripture] copied, so that she on a daily basis may recite it, [hoping that her] former karma and transgressions may be reverted and all sentient beings may quickly attain enlightenment. ${ }^{34}$

31 Even though it is well-established that traditional Indian Buddhism also promoted filial piety, including the respect for elders, its manner of conceptualisation and role in Buddhist practice is of quite another order. Here, and in the related material from Dunhuang, it is quite clear that Sinitic norms were the most common modus (it would be strange otherwise, as the population of Dunhuang during the medieval period, such as that we deal with here, was dominated by Chinese).

32 For a good example of the motives for dedicating a religious painting, see Sørensen, 'Donors and Image at Dunhuang'. See also the classical study by Soymié, 'Les donateurs dans les peintures de Dunhuang'.

33 no. 998, 19. See also Cf. Lin and Shen, Dunbuang mizong wenxian jicheng, 291-96.

34 Beijing 7321: 乙丑年一月 十六日在瓜州, 比丘尼智清發心, 拎寫常日轉讀, 前業罪回顛, 皆情眾其世速登心覺. 
Given that the accumulation of good karma is Zhiqing's primary motive of, her choice to have the Parināmacakra-sütra copied makes good sense. In this particular case, she wants to have the scripture copied for her own use and not as a donation to be given away. Even so, she clearly states that she intends to recite it on a daily basis for the expiation of her own evil karma and with the wish that the merit be extended to all sentient beings.

Another similar case, and also without other motives than the generation of good karma, involves the copying of three popular scriptures:

On the 8th day in the 4th month of the 6th year of the Xiande [reign-period] of the Great Zhou (i.e. Later Zhou, 959 CE), Master Huiguang of the Chengdian Chan Cloister in Guazhou respectfully decided to have the three rolls of the Yanshou ming jing, the Xuming jing and the Devatä-sütra ${ }^{35}$ copied, in a total of forty-nine rolls. At the same time wanting to be a donor, [hereby] announcing appropriately the pure auspiciousness. Eternally bestowed as an offering. ${ }^{36}$

In connection with this copying of scriptures, one may speculate that the number of forty-nine rolls is hardly coincidental as it corresponds to the pattern of the Seven-seven Rite (qiqi 七七). In other words, this undertaking may very well reflect on mortuary beliefs and practices as well.

The Guanshiyin jing 觀世音經 [Avalokiteśvara Scripture] is another popular scripture, which enjoyed considerable popularity among Dunhuang's Buddhists. It is in fact not a proper sutra, but is the celebrated Pumen pin 普門品 [Pumen Chapter] of the Saddharmapundrika, ${ }^{37}$ which circulated as an individual scripture. It was copied numerous times locally by lay-people as well as by clerics. One case involving a member of the latter has a colophon which reads:

35 T no. 592, 15.

36 P. 2374: 維大周顯德六年四月八日, 瓜州承典禪院師惠光, 發心敬寫《延壽命 經》, 《續命經》, 《天請問經》三卷, 計寫四十九卷. 同發心施主, 報宜清吉, 永充供養.

37 Tno. 262, 9: 56c2-58b7. 
The time being the 28th day of the 11th month in the $3 \mathrm{rd}^{38}$ successive wuyin year [i.e. $918 \mathrm{CE}$ ], the monk Haiman of the Baoen Temple decided to have this scripture in one roll copied. Respectfully on behalf of the previously deceased parents, [praying that] they will not drown in the netherworld, but be transported on this good cause, eventually reaching [the assembly of] Maitreya, and that those in existence will likewise have their karmic screens utterly eliminated. Eternally given as an offering. Copied from the hand of the monk Shengzhi. ${ }^{39}$

Here we have a case which shows that the motives for scriptural donations of both clerics and laity were by and large the same. Here the donated scripture, i.e. the Avalokitesvara Scripture, is not specifically related to mortuary practices, although as a bodhisattva, Avalokiteśvara is of course a major saviour. Although Maitreya's paradise or assembly in the future is invoked, it is interesting that an entirely different scripture was offered. Although it is not stated explicitly, it is highly possible that Haiman personally copied out the scripture in question.

Another case concerns the Foshuo zhaifa qingjing jing 佛說齋法清 淨經 (Buddha Utters the Zhaifa Scripture on Purification), yet another popular apocryphal scripture, which circulated among the Buddhists in Dunhuang. ${ }^{40} \mathrm{~A}$ donor dedication appended to a copy of this scripture from $960 \mathrm{CE}$ provides the following terse piece of information:

Foshuo zhaifa qingjing jing in one roll. On the 3rd day of the 1 st month in the 7th gengshen year of the Xiande reign-period of the Later Zhou, [this scripture was offered by] the faithful disciple Yao Xian, who with a disposition of piety continues to recite this one-roll scripture. ${ }^{41}$

38 Actually the fourth year of that reign-period.

39 S. 3054: 時貞明三年歲次戊寅十一月廿八日, 報恩寺僧海滿, 發心敬寫此經 一卷. 奉為先亡考妣, 不溺幽冥, 乘此善因, 早過彌勒. 現存之者, 所有業鄣並皆消 滅. 永充供養. 比丘僧勝智手寫. See also the translation in Giles, 87a.

40 T no. 2900, 85.

41 Ryūkoku University Library no. 739: 《佛說齋法清淨經》一卷. 後周顯德七 年庚申歲次正月三日. 信士弟子姚賢者信心讀誦此經一卷. 
Just like the example quoted above involving the nun Zhiqing, this layperson also had the scripture copied for personal use; as a means of creating good karma. This is yet another example that Buddhist scriptures of this type, were produced for a variety of purposes: not only for purposes of donation in connection with transference of merit, but also as part of personal religious cultivation. Brief as this information is, it does inform us about Buddhist practice on the proverbial ground.

From the perspective of patronage and provider of donations to the local Buddhist community, the Zhai clan 翟氏 stands out among the powerful families in Shazhou. The history of this clan and its involvement with Buddhism goes back to the late Nanbeichao period and grew exponentially in the course of the Tang. ${ }^{42}$ The clan is known to have been behind the excavation of at least two caves in Mogao, nos. 85 and $220 .{ }^{43}$ In addition, its members participated in various collective works, including the excavation of cave no. 61, which appeared to belong to the Cao clan because Cao Yuanzhong 曹元忠 (r. 944-974) was married to a lady of the Zhai clan. ${ }^{44}$ Women of this clan also appear among the donors in the Yulin caves (nos. 19, 25 and 36$).{ }^{45}$

We have additional information on Lady Zhai in a colophon dated to $953 \mathrm{CE}$, which records the donation of forty-three copies of the Yan shouming jing 延壽命經 [Scripture on the Augmentation of the Span of Life ${ }^{46}$ on the occasion of the death of her son. It goes:

42 For a highly important study of the history of this clan, see Chen, Dunbuang Zhai shi yanjiu. This remarkable and dense study documents the history of the Zhai clan on the basis of the Dunhuang manuscripts and other epigraphical material, as well as religious paintings.

43 Dunhuang yanjiuyuan, Dunhuang Mogao ku gongyang ren tiji, 29-30, 101-4. Cave 220 is the main topic of the monograph by Ning, Art, Religion and Politics in Medieval China.

44 Dunhuang yanjiuyuan, Dunbuang Mogao ku gongyang ren tiji, 20-25. See also Chen, Dunbuang Zhai shi yanjiu, 189-94.

45 Cf. Chen, Dunbuang Zhai shi yanjiu, 194-95.

46 no. 2888,85 , etc. 
On the twenty-third day of the first month in the third guichou year of the Guangshun [reign-period] (i.e. $953 \mathrm{CE}$ ) under the Great Zhou, the Great Protector and Lord of the Yamen (Ch. fuzbu dabao 府主大保 $)^{47}$ together with his wife, on behalf of the deceased male prince early in the morning in the annex to the royal palace (bie wanggong 別王宮), had forty-three volumes of the Yan shouming jing copied. With the power of the merit of the meagre feast they pray that he will surpass the path to enlightenment. Eternally bestowed as an offering. ${ }^{48}$

Here we have a good example of a private donation made by the ruling family. The choice of copying and donating the Yan shouming jing in relation with a death in the family of course appears to be an obvious one. Moreover, as we shall presently see, this particular apocryphal scripture was evidently enjoying a considerable popularity among local Buddhists in Dunhuang during the mid- to late tenth century. ${ }^{49}$

\section{Zhai Fengda and the Vajracheedikā}

One case of scriptural production as offerings by a private agent that stands out from among the other ones discussed previously, concerns a leading member of the same Zhai clan dealt with in the previous case. Namely the case of the local government official Zhai Fengda 翟 奉達 (881-961?), ${ }^{50}$ who produced a series of different Buddhist scrip-

47 This refers to Cao Yuanzhong.

48 Ryūkoku Library No. 2343: 維大周廣順三年當癸丑正月廿三日, 府主太保 及夫人, 為亡男太子早別王宮, 棄辭火宅, 遂寫《延壽命經》四十三卷, 以濟福力. 願超覺路, 永充供養.

The text has been taken from Wang, Dunbuang wenxian tiji bian nian ji qi fenxi.

49 For the importance of apocryphal scriptures in Dunhuang, see the survey in Liu, 'Dunhuang xiejuan zhongtu caojing de jiushu xixiang tiyao'.

50 Cf. Li, ed., Dunbuang xue da cidian, 363b. See also, Tao and Jiang, comp., Dunbuang suijin, 92-93. 
tures on a variety of occasions, the most celebrated case being those presented as part of the commemoration rites accompanying the passing of his deceased wife Madame Ma 馬氏 (fl. tenth century). ${ }^{51}$ Here the focus will be on one of the earliest Buddhist scriptures produced by Zhai Fengda, namely the copy he made of the Vajracheedika-sütra, ${ }^{52}$ together with a record of miracle stories centering on the same scripture, the Chisong Jingangjing lingyan gongde ji 持誦金剛經靈 驗功德記 (Records of the Merit of Divine Response from Chanting the Vajracheedikā). ${ }^{53}$ Zhai Fengda's copying of the Vajracheedika an interesting example of how a popular canonical scripture in the course of time could evolve and change from a primarily important doctrinal work to one in which the core message fell somewhat in the background, and where its ascribed numinosity and transcendent status came to the fore. Fengda's colophon that accompanies his copy of both texts reads:

Written on the 9th day in the 4th month in the 8th wuchen year of the Tianhou reign-period of the Tang ${ }^{54}$ by the commoner (buyi 布

51 Zhai Fengda's case has been studied extensively in Teiser, The Scripture of the Ten Kings, 102-21.

$52 T$ no. $235,8$.

$53 T$ no. 2743,85 . This work is a short collection of miracle tales meant to highlight the Vajracheedikā-sütra's claim to fame. It was ostensibly compiled sometime during the Kaiyuan period, as it features a lengthy accompanying verse attributed to Xuanzong 玄宗 (r. 712-741): the Kaiyuan Huangdi zan Jingang jing gongde 開元皇帝讚《金剛經》功德 [Praising the Virtue of the Vajracheedika Sutra]. Cf. T no. 2743, 85: 159a27-159c9.

54 This year does not exist in formal Chinese chronology as this Tang dynasty reign only lasted three years ending in $903 \mathrm{CE}$. Hence Tianfu 8 actually corresponds to the second year of Kaiping 開平 of the Later Liang 後梁 (907-922). In regard to the date in Zhai Fengda's colophon, it is interesting that he was seemingly unaware that the Tang dynasty itself had ended a full two years prior. This means that Shazhou and the rest of the western parts of Hexi 河西 were effectively cut off from contact with the central provinces of China between $902 \mathrm{CE}$ and well into the second or third reign-periods of the succeeding Liang dynasty, 
衣) Zhai Fengda. This scripture of extolling the records of the merit for [divine] responses [is meant] to increase its circulation. Moreover [it was copied] on behalf of the faithful, as well as the departed souls (Ch. wang wangling 往亡靈), and his parents, who are still alive (Ch. jianzai 見在) to be joined by [the people] of the district, so that they may [all] share in the blessings. As certain as [the sprouting] Spring grasses, transgressions surely will resemble the autumn's harvest. May all come together and appear in the assembly of [Maitreya] Buddha. ${ }^{55}$

The text of the dedication is reasonably plain, and underscores Zhai Fengda's piety and fervent wishes for his fellow human beings and the members of his own family in particular. However, despite the fact that it shares most of the same concerns as other donor dedications, it is also a bit more serious, even a bit more philosophical, and its leaves us in no doubt that he was a devoted Buddhist and adherent of the Vajracheedika

Following the dedication and its wish for transference of the accrued merit, Zhai Fengda's editorial note following the main text of the sütra states:

The commoner, the disciple Zhai Fengda relying on the contents of the edition of the Sichuan printed text, has copied the numbered divisions and the mantras from this sutra [thereby] augmenting it by combining the diverse parts that have [previously] been left out. ${ }^{56}$

The printed Sichuanese edition of the Vajracheedika mentioned by Zhai Fengda here undoubtedly refers to the celebrated version of the sütra, which was published by a person named Wang Jie 王玠 (d.u.) on behalf of his parents in $868 \mathrm{CE} .{ }^{57}$ The additional material

or at least until the time of the de facto collapse of rule by the Zhang clan in or around 910-915 CE.

55 P. 2094. See also Teiser, The Scripture of the Ten Kings, 119. My reading differs greatly from his.

56 布衣弟子翟奉達，依西川印出本內，抄得分數及真言，於此經內添之，兼遺 漏分也. 
which Zhai Fengda added to the printed version of the sutra-or as it were-to its liturgical parts is especially interesting for us here. A comparison with these same texts from the printed Sichuanese edition of the Vajracheedika (here referred to as the beta text), reveals that it features a significantly different arrangement in which the scripture was meant to be performed.

The printed text of Sichuan begins by stating:

Those who wish to recite the scripture must first invoke the Jing kouye zhenyan 淨口業真言 (Mantra for Purifying the Karma of the Mouth):

Suri suri mahāsuri susuri svāhā.s8

脩唎 脩唎 摩訶脩唎 脩脩唎 娑婆訶.

Then follows the invocations of the Eight Vajrapālas:

I respectfully invite the Vajrapāla Remover of Calamities

I respectfully invite the Vajrapāla Deviant Poison

I respectfully invite the Vajrapāla Yellow

I respectfully invite the Vajrapāla Clear Pure Water

I respectfully invite the Vajrapāla Red Voice.

I respectfully invite the Vajrapāla Fixed Remover of Adversities.

I respectfully invite the Vajrapāla Purple Virtue.

I respectfully invite the Vajrapāla Great Spirit. ${ }^{59}$

Or. 8210/P.2

58 凡欲讀經先念淨口業真言一遍.

59 奉請 除災金剛

奉請 闢毒金剛

奉請 黃隨求金剛

奉請 白淨水金剛

奉請 赤聲金剛

奉請 定除厄金剛

奉請紫賢金剛

奉請大神金剛. 
After this invocation follows the text of the Vajracheedika itself. At its conclusion comes the mantra:

Namo bhagavate prajñ $\bar{a}^{60}$ pāramitāya om ìriti ịsiri śruta viśāya viśāya svāhā.

In contrast to this, Zhai Fengda's arrangement of the liturgical text accompanying the sütra places all the performative aspects relating to the Vajracheedika before the text of the sütra itself. It reads as follows:

As for those who wish to revolve and recite (zhuannian 轉念) the Vajracheedikā-prajñāpāramitā-sütra, it is necessary first to invite the Eight Great Vajrapālas by their names, and extend one's mind to 發 至誠心. Afterwards one may revolve and recite the scripture. These Eight Vajrapālas will come on their own accord and always render protection to the person, who upholds the scripture. ${ }^{61}$

Then follows the invocation of the Eight Vajrapālas:

1. I respectfully invite the Vajrapāla Green Remover of Calamities, who is able to remove astral calamities (suzai 宿災), disasters and punishments of all sentient beings. Make sure to cause the obliteration of calamities (Note: He dwells in the great ocean).

2. I respectfully invite the Vajrapāla Deviant Poison, who is able to remove the sufferings of all sentient beings caused by fever, poison and diseases (Note: He is the lord, who removes calamities caused by poison).

60 boluorang 鉢羅壤. This is a slightly odd rendering of the Sanskrit 'prajun $\bar{a}$, but not entirely unheard of.

61 凡欲轉念金剛般若波羅蜜經者. 先須啟請八大金剛名字. 發至誠心. 然後轉 念經. 此八金剛自來常當擁護持經之人. 
3. I respectfully invite the Vajrapāla Yellow One According with Wishes, who is able to cause all sentient beings to obtain what they seek in accordance with their prayers (Note: $\mathrm{He}$ is the lord of underground sources of virtue).

4. I respectfully invite the Vajrapāla, Clean and Pure Water, who is able to remove the sufferings caused by hot anger of all sentient beings, make sure to obtain the removal and elimination of them (Note: He is the lord of all treasures).

5. I respectfully invite the Vajrapāla Red Voice, who is able to illumine all sentient beings with bright light, so that they may behold the Buddha (Note: He is the lord able to create wind).

6. I respectfully invite the Vajrapāla, Remover of Fixed Calamities, who is able to remove the three kinds of calamities of all sentient beings as well as the sufferings of the Eight Hardships. ${ }^{62}$ (Note: He is the lord of precious things).

7. I respectfully invite the Vajrapāla Purple Virtue, who is able to cause the minds of all sentient beings to become awakened and give rise to the mind of enlightenment (Skt. bodhicitta) (Note: $\mathrm{He}$ is the lord of prisons and dungeons).

8. I respectfully invite the Vajrapalla Great Spirit, who is able to cause all sentient beings [to have] wisdom teeth, so that they may accomplish the power of knowledge and the augmentation of everything (Note: The is the lord of the Dragon Kings [Skt. nāgarāja]). ${ }^{63}$

62 I.e. those reborn in the hells, as a preta, as an animal, in the Northern Continent of Uttatakuru, in the heavens, as someone with impaired faculties (i.e., deaf, blind and dumb), as a philosopher and as someone born in the period between the appearance of two Buddhas.

63 第一. 奉請青除災金剛, 能除一切眾生宿災殊各悉令消滅 (主大海).

第二. 奉請僻毒金剛, 能除一切眾生熱毒病苦 (主除災毒). 
Immediately following the invocation and invitation to the Eight Vajrapālas, Zhai Fengda's text presents an extended series of spells as follows:

Dashen zhenyan 大身真言 [Mantra of the Great Body ${ }^{64}$ ]:

Namo bhagavate prajñ $\bar{a}^{65}$ pāramitāya om ìriti ịsiri śruta viśāya viśāya svāhā. ${ }^{66}$

This is followed by the

Suixin zhenyan 隨心真言 [Mantra for According with One's Intentions]: Namo bhagavate prajñ $\bar{a}^{67}$ pāramitāya dusta om hum vajra svāhā.

那謨 薄迦筏帝 鉢喇惹 波羅蜜多曳 怛姪他 唵吽68 筏折羅 褿麗 乷婆 訶.

第三. 奉請黃隨求金剛, 能令一切眾生所求如願所願皆得 (主堈溜功德).

第四. 奉請白淨水金剛, 能除一切眾生熱惱苦悉得消除 (主一切寶).

第五. 奉請赤聲金剛, 能照一切眾生光明所得見佛 (主能生風).

第六. 奉請定災除金剛, 能除一切眾生三災八難之苦 (主瑠璃寶).

第七. 奉請紫賢金剛, 能令一切眾生心開悟解發菩提心 (主堅牢藏).

第八. 奉請大神金剛, 能令一切眾生智牙成就惠力增具 (主龍王).

${ }^{64}$ Dharmakāya? This spell can be found added to Kumārajīva's celebrated translation of the Vajracheedikā from 401 CE. Cf. T no. 235, 8: 752c5. However, it is rather unlikely that the sutra and the spell were part of the same textual complex at such an early time.

${ }^{65}$ boluorang 鉢羅壤. This is a slightly odd rendering of the Sanskrit 'prajñ $\bar{a}$, but not entirely unheard of.

66 那謨婆伽箋帝鉢羅壤 波羅蜜多曳唵伊利底 伊室利 輸盧駄 毘舍耶 毘舍耶 娑婆訶. An alternative, and perhaps more meaningful rendering could be: Namo bhagavatī prajñā pāramitāya oì hrìh śrì śruti vijaya svahā. However, the spelltext in Zhai Fengda's rendering does not really allow for it.

67 Ch. bolare 鉢喇惹. This is a slightly odd rendering of the Sanskrit 'prajñ $\bar{a}$, but not entirely unheard of. 
Next come the,

Xin zhong xin zhenyan 心中心真言 [Heart of Hearts Mantra]:

Om karunisa ${ }^{69}$ svābā. ${ }^{70}$

Followed by the,

Jingang er zhou 金剛兒呪 [Spell of the Vajra Lad]:

Namo Vajrakumāra kaṇi dhuan ${ }^{71}$ svāhā..$^{72}$

Followed by the,

Fomu zhou 佛母呪 [Spell of the Buddha Mother]:

Namo dhasa namo dha/takunam om buru buru siddha locani sarvārtha sadhani svāhā. ${ }^{73}$

And finally we have,

Wenshu pusa xinzhong zhenyan 文殊菩薩心中真言 [Mañjuśrīs Heart Mantra]:

68 Here the Taishō text wrongly has ' $b u$ 呼'. Cf. T no. 2743, 85: 2.160a6.

69 This would seem to the result of a simple copyist mistake, and should in all likelihood read, karunikā, i.e. 'Compassionate One'. It is also possible that the sha 沙 as found here occurred as a doubling of the following suo 莎.

70 唵 鳴倫泥沙 莎婆訶.

71 This should read 'dbuni' in Sanskrit. It may be a case of phonetics gone wrong, or simply a spell that has been differently transmitted. When comparing this with the original spell from the Mabavvairocana-sütra, this seems the most likely explanation for the anomalously written spell in Zhai Fengda's text.

72 南無 跋折鳩魔囉 迦儞度闇 莎訶.

73 南謨 陀舍 南無 陀俱南唵 戶嚕 戶嚕 死陀 盧遮儞 薩囉 乷囉他 乷達儞 莎 訶. 
A rapasa $n a .^{74}$

Those persons, who set their minds on chanting this mantra, will be similar to having chanted the entire Tripitaka once. ${ }^{75}$

This ends the instructions for the liturgical procedure in preparation for the recitation of the Vajracheedika itself. After this a short note appended the end of the text states:

In Sanskrit it is stated: How may we with this suttra reach the other shore? We pray that the Buddha will open its secrets (weimi 微密) to us, and that he will widely, on behalf of all sentient beings, discourse on it while turning the Great Dharma Wheel. ${ }^{77}$

The first in the series of spells constituting the major part of Zhai Fengda's beta text is the Dashen zhenyan. Its origin is somewhat oblique, but it would appear to have been composed in India (or an Indic cultural setting) some time between the late seventh century and the early eighth century. It is the primary spell accompanying the Vajracheedik $\bar{a}$, and as such reflects the growing interest in magic and soteriological shortcuts that took place in mainstream Mahāyāna from the fourth century onwards. This spell first appears in the Chinese sources around the beginning of the eighth century, and at that time it was already an appendix to the Vajracheedika. The Fangshan 房山 stone-carved edition from $683 \mathrm{CE}$ does not have the spell, nor any other liturgical aspects. ${ }^{78}$ At a closer look the spell-or mantra as it is referred to in the Dunhuang manuscript under discussion-appears to be at least partly based on the Bodosnnișa-dhärani translated by Bodhiruci. In any case it is conspicuous how several consecutive segments of phrases in the two spells correspond. Note

\footnotetext{
74 阿羅 波遮那.

75 凡人至心誦此真言者. 猶誦天下藏經一遍也.

76 The text has 'weimi' 微蜜, which would appear to be a scribal mistake.

77 梵音云: 何於此經究竟到彼岸. 願佛開微蜜. 廣為眾生說轉大法輪.

78 For this version, see Fangshan Yunju si shijing, pl. 17a.
} 
that both this spell and the two ones following it are referred to as 'mantras'. As a category of spells, mantras are one of the hallmarks of mature Esoteric Buddhism and only appear in primary sources with this designation after the beginning of the eighth century.

The Suixin zhenyan, as we have it here, is obviously derived from the Dashen zhenyan, as it features a similar structure and shares primary elements. As such, it represents a spell sub-category meant as an accessory to a major spell of a given rite such as the Dashen zhenyan.

As for the Xin zhong xin zhenyan, it is very short and carries nothing in it, which may lead one's thoughts directly to the Vajracheed$i k \bar{a}$. While there certainly is a tradition for appending it to the suttra in question, it is unclear from which source it originally derived.

The Jingang er zhou as we find it here is in a variant form, one that has not been similarly documented in any of the Chinese canonical compilations. Its earliest form is undoubtedly that found in the Vajrakumāra tantra complex of scriptures, where it appears as part of a much longer and complete spell. ${ }^{79} \mathrm{~A}$ comparison reveals that the spell used by Zhai Fengda is the same as a minor mantra used in connection with the forming of a mudrā in the variant version of Amoghavajra's translation of the Vajrakumàra tantra, but rendered in an entirely different transcription. ${ }^{80}$ We do not know exactly how the spell in Zhai Fengda's beta text came about. But given that the textual tradition of the Mabāvairocana-sütra was not transmitted to Dunhuang, we may exclude that as the possible source for the spell he used. Vajrakumāra otherwise occurs in a number of other texts found among the Dunhuang manuscripts. ${ }^{81}$

A comparative look at the Fomu zhou indicates that it is largely identical with another spell, the Libai miezui mingzhong zhu fo laiying zhou 禮拜滅罪命終諸佛來迎呪 [Spell for Making Prostrations for the Elimination of Wrongdoings so that at the End of One's Life One will be Welcomed by all the Buddhas], found in the spell-compendium, the Zhongzhong za zhou jing 種種雜咒經 [Scripture Con-

\footnotetext{
79 Tno. 1223, 21: 132c4.

80 Tno. 1222B, 21: 121a29.

81 Cf. P. 3861, S. 3783, etc.
} 
sisting of Various Kinds of Spells]. ${ }^{82}$ Again, it is almost certain that this spell-collection was not available to Zhai Fengda, or anyone else in Dunhuang for that matter, wherefore we may rule out any direct link between the two as we have them now. Obviously the Fomu zhou represents a sort of hybrid text, possible slightly garbled, but also one that shifted ritual context in the course of time. Not only does this demonstrate the volatile and disenfranchised nature of many Buddhist spells more generally speaking, something which is likely to have been further engendered through translation into Chinese, its transmission and replication by people who had no mastery of Sanskrit or knowledge of the original context for which it was used. The identity of the 'Buddha Mother', whose spell it is, is debatable, but the name most likely refers to Prajñāpāramitī, the Goddess of Wisdom, who the spell connects with the cult of the Vajracheedika.

The Wenshu pusa xinzhong zhenyan we encounter in Zhai Fengda's spell list consists of five seed syllables (Skt. bijā), each of which represent a potent, spiritual quality. The origin of this mantra is the most probably the Jin'gangding jing yuqie Wenshushili pusa gongyang yigui 金剛頂經瑜伽文殊師利菩薩供養儀軌 [Ritual Proceedings for Making Offerings to the Bodhisattva Mañjuśrī in Accordance with the Yogā of the Vajraśekhara-sūtra], another translation by Amoghavajra, which forms part of the Vajrasekhara-cycle of Esoteric Buddhist scriptures. The five letter spell occurs a number

82 T no. 1337, 21: 638b24-638c1:

Namo buddhāya om buru huru siddha locani sarvārtha sadhani svāhā.

南謨-母䭾野唵戶嚕戶嚕 悉䭾 盧者儞 娑囉 皤囉他 娑䭾儞 娑婆訶.

The same spell also circulated in a another variant form, as part of the Southern Song compilation, the Rulai guangxiao shizhong baoen daochang yi ( $W$ no. 68, 8: 7.313a9). There it appears as:

Namo dhakanam buddhāchinam om buru buru siddha locani sarvārtha sadhani svāhā.

南無, 陀舍喃, 蒲陀俱知喃, 唵, 護嚕, 護嚕, 悉陀, 盧者你, 薩婆羯他, 娑達 你耶, 娑婆訶.

As can be seen, this version-especially its first part-is closer to the one used by Zhai Fengda, although it would appear to be more correct. 
of times in this ritual text. ${ }^{83}$ It is peculiar that the cult of Mañjuśri was grafted onto the Vajracheedika as we see it here, especially because this otherwise important bodhisattva is normally not associated with this sütra. Even so, we must assume that, like most of the other spells in Zhai Fengda's beta text, it was added on as an extra, auspicious, and protective factor.

As far as the information and presence provided by these spells go, we may note that by the early ninth century, spell-related practices had found their way into virtually all forms of Buddhist practice, even appearing in new textual contexts in which they were not originally found. However, within the context of tenth century Buddhism in Dunhuang, we can find a cluster of Buddhist practices such as these that were originally part of distinct textual and performative complexes, which have been de-contextualised and rearranged to function in a variety of new ways. I would see this trend as reflecting on the increasing popularity and significance of Esoteric Buddhism in Chinese Buddhism broadly understood, i.e. as a ritualisation of textual practices, and not just as the addition of a few magical words to an already profound and holy scripture.

As is immediately clear, we can see that Zhai Fengda's text is not only much more extensive than that of the printed Sichuan edition, it also displays a number of variations, including the texts for invoking the Vajrapālas, and the opening spell. Furthermore, the Mantra for Purifying the Karma of the Mouth is entirely absent. We may also note that the applied method of transcribing the spells differs considerably, although roughly the same phonetic structure applies. Moreover, it is interesting-although not entirely surprising-that several of the spells in Zhai Fengda's beta text correspond with those we encounter in the Liangchao Fu dashi song Jingang jing 梁朝傅大 士頌金剛經 [Fu Dashi of the Liang Court's Song on the Vajrachee$d i k \bar{a}$ ]. This lengthy text features a blend of the printed Sichuan version's spells and those of Zhai Fengda. ${ }^{84}$ This indicates that the spells appearing in connection with the sütra were circulating in

\footnotetext{
$83 T$ no. $1175,20: 722 \mathrm{c} 13$.

$84 T$ no. 2732, 85: 8c13-8c20.
} 
Dunhuang in more or less fixed forms during the early tenth century. It would appear-although this is based on conjecture-that Zhai Fengda's text actually more geared towards ritual or performative practice than the printed Sichuan version with its much-reduced beta text.

What is perhaps even more significant than the texts in the manuscript themselves, is the fact the manuscript was copied by Zhai Fengda himself. Therefore, this represents and expresses his personal devotion to the sutra in question, and the related cultic activities that surrounded the cultivation of its teachings, not the least the chanting of its text and the spells that go with its worship.

\section{Conclusion}

Public and, more specifically, organised monastic projects for producing and re-producing Buddhist scriptures, were by their very nature would be more labour intensive and also more costly. They were evidently the most efficient manner of transmitting and preserving Buddhist scriptures in Dunhuang during the period of manuscripts. Being focused projects undertaken by Buddhist specialists, often assisted by outside funding, such reproduction primarily aimed to supply and amend the holdings of the local monastic libraries. This, of course, does not exclude the fact that sets of scriptures produced for monasteries by the local leaders, including the powerful clans, were not also donated with the idea of religious merit behind them. In contrast, the copying of individual Buddhist scriptures was often the result of private undertakings. As I have shown here, these individual enterprises were also aimed at achieving different objectives, namely the accumulation of merit for the agent, and for a variety of other purposes as outlined above. While we may imagine that most of these many scriptures reproduced in this manner ended up in monastic libraries as donations, some were surely kept by the agents for personal use. Indeed, many are likely to have been brought away from Dunhuang by pilgrims and travellers, which secured that a given scripture would potentially have enjoyed a wide circulation.

Among ordinary clerical and lay Buddhists, the sources show that it was popular to have short apocryphal scriptures copied. In fact, we 
may even go so far as to insist that when it came to private, small-scale scriptural donations, the surviving donors' colophons clearly indicate that apocryphal scriptures were indeed favoured over canonical sütras. The only major exceptions to this being the Vajracheedike $\bar{a}$, the Prajñāpāramitā-brdāya-sütra, and less commonly the Pumen Chapter of the Saddharmapundarika.

It is an indisputable fact that many donations and offerings of scriptures that we see at Dunhuang during the period under discussion took place as part of merit-making. Especially in the context of the transference of merit. This means that these scriptural donations and offerings were often, although not always, related to mortuary practices.

In the case of Zhai Fengda copying the Vajracheedika and its accompanying volume of miracle tales, we see how individual scriptural production could, in some cases, alter the format or change the manner in which a given Buddhist scripture was being perceived. In the case given here, we see how the additional material added to the sutra itself, what is referred to as the beta text, reflects a heightened sense of its ritual importance. It is not clear to what extent Zhai Fengda was an adept of spell-lore per se, but based on our reading of the beta text, it certainly appears that he had a special interest in Esoteric Buddhist practices. This tallies rather well with what we otherwise know about Buddhism in Dunhuang during the tenth century.

Finally, and although this is not an issue discussed in any detail in this paper, it would appear that Dunhuang never had what amounted to a complete set of the Buddhist Tripitaka in Chinese, at least not in manuscript form. While this observation is admittedly based on the extant material from cave no. 17, I believe we still have to see documentation to the contrary. When it came to manuscript production and re-production, Dunhuang evidently had what amounted to a partial Tripitaka only. However, it had an abundance of extra-canonical material to make up for this. 


\section{Bibliography}

Abbreviations

P. Pelliot Collection in the Bibliothèque Nationale

S. Stein Collection in the British Library

T Taishōshinshū daizōkyō 大正新脩大蔵経. See Bibliography, Secondary Sources, Takakusu and Watanabe, eds.

Tianjin Dunhuang manuscript collected in the Tianjin Library

$W \quad$ Zangwai fojiao wenxian, first series, 1-10

ZZ Dai Nihōn zōkuzōkyō, 98 vols. (modern edition)

\section{Primary Sources}

Banruo boluo miduo xinjing 般若波羅蜜多心經

[Hridāyaprajūāpāramitā-sūtra]. 1 juan. Trans. by Xuanzang 玄 牀 (602-664) between 648-649. T no. 251, vol. 8.

Chisong Jingangjing lingyan gongde ji 持誦金剛經靈驗功德記

[Records of the Merit of Divine Response from Chanting the

Vajracheedikā]. 1 juan. Author unknown. T no. 2743, vol. 85 .

Da boniepan Moye furen pin jing 大般涅槃摩耶夫人品經 [i.e.

Fomu jing 佛母經, Sūtra of the Mother of the Buddha]. 1 juan.

Translator unknown. T no. 2919, vol. 85 .

Da banruo boluomiduo jing 大般若波羅蜜多經

[Mahāprajūāpramitā-sütra]. 600 juan. Trans. by Xuanzang 玄牀

(602-664) between 660-663. T no. 220, vol. 8.

Dafoding da tuoluoni 大佛頂大陀羅尼 [The Dhäranī of the Great

Śitātapatra]. 1 juan. Compiler unknown. T no. 944b, vol. 19.

Dafoding rulai fangguang sidaduobodaluo tuoluoni 大佛頂如來放

光悉怛多鉢怛囉陀羅尼 [The Dhārañ of the Light-Emitting

Sitātapatra, Great Corona of All Tathāgatas]. 1 juan. Trans. by

Bukong 不空 (Amoghavajra, 705-774) sometime between 756 and 774. T no. 944a, vol. 19.

Foshuo foming jing 佛說佛名經 [Buddhanāmas sūtra]. 30 juan.

Translator unknown. T no. 441, vol. 14.

Foshuo buixiang lun jing 佛說迴向輪經 [Parināmacakra-sūtra]. 1

juan. Trans. by Shiluodamo 尸羅達摩 (fl. 785-805) in 790. T no. 
998, vol. 19.

Foshuo Molizhitian pusa tuoluoni jing 佛說摩利支天菩薩陀羅

尼經 [Marīci-devī sūtra]. 1 juan. Trans. by Bukong 不空

(Amoghavajra, 705-774) sometime between 756 and 774 . $T$ no.

1255a, vol. 21.

Foshuo Molizhitian tuoluoni zhou jing 佛說摩利支天陀羅尼呪經

[Marīì-devī sütra]. 1 juan. Translator unknown. T no. 1256, vol. 21.

Foshuo Shuiyueguang Guanyin pusa jing 佛說水月光觀音菩薩經

[Sütra on the Water and Moon Avalokiteśvara Bodhisattva]. 1

juan. Author unknown. $W$ no. 11, vol. 1.

Foshuo wuchang jing 佛說無常經 [Anityatā-sütra]. 1 juan. Trans. by

Yijing 義淨 (635-713) in 701. T no. 801, vol. 17.

Foshuo Wuliangshoufo buashen dafenxun Jumoluo jin'gang niansong

yuqie yigui fa 佛說無量壽佛化身大忿迅俱摩羅金剛念誦瑜伽

儀軌法 [Ritual Proceedings for the Recitation of the Yoga of

Amitāyus Transformed into Vajra Kumara]. 1 juan. Trans. by

Jin'gangzhi 金剛智 (Vajrabodhi, 669-741) sometime between

723-741. T no. 1223, vol. 21.

Guanyin jing 觀音經 [Sūtra of Guanyin (originally the 'Pumen

Chapter' of the Lotus Sutra)] in Miaofa lianhua jing 妙法蓮華

經 [Saddharmapundarika-sütra]. 7 juan. Trans. by Jiumoluoshi

沜摩羅什 (Kumārajīiva, 344-413) in 403. T no. 262, 9: 7.56c1$58 \mathrm{~b} 7$.

Hu zhu tongzi tuoluoni jing 護諸童子陀羅尼經 [The Dharani

Sütra on the Protection of Young Children]. 1 juan. Trans. by

Putiliuzhi 菩提流支 (fl. 508-534) ca. 508. T no. 1028A, vol. 19.

Jin'gang banruo boluomi jing 金剛般若波羅蜜經 [Vajracheedikā]. 1

juan. Trans. by Jiumoluoshi 鳩摩羅什 (Kumārajīva, 344-413) ca.

403. $T$ no. 235 , vol. 8 .

Jin'guangming zuisheng wang jing 金光明最勝王經

[Suvarnaprabhāsa-sūtra]. 10 juan. Trans. by Yijing 義淨 (635-

713) in 703. T no. 665, vol. 16.

Jin'gangding jing yuqie Wenshushili pusa gongyang yigui 金剛頂 經瑜伽文殊師利菩薩供養儀軌 [Ritual Proceedings for Making Offerings to the Bodhisattva Mañjuśrī in Accordance with the Yogā of the Vajraśekhara-sūtra]. 1 juan. By Bukong 不空 
(Amoghavajra, 705-774) sometime between 756 and 774. Tno. 1175, vol. 20.

Kaiyuan Shijiao lu 開元釋教錄 [Kaiyuan Catalogue of the Buddhist Teachings]. 20 juan. Completed by Zhisheng 智昇 (fl. 700-786) in 730 . $T$ no. 2154 , vol. 55 .

Liangchao Fu dashi song Jin'gang jing 梁朝傅大士頌金剛經 [The

Diamond Sütra Recited by Fu Dashi]. 1 juan. Compiler unknown. T no. 2732, vol. 85 .

Miaofa lianbua jing 妙法蓮華經 [Saddharmapundarika-sūtra]. 7

juan. Trans. by Jiumoluoshi 鳩摩羅什 (Kumārajīva, 344-413) in 403. T no. 262, vol. 9.

Qianjin yifang 千金翼方 [Medical Formulas Worth a Thousand Gold Pieces]. 30 juan. By Sun Simiao 孫思选 (541?-682) completed ca. 682. Accessed on April 3, 2018. http://seirouoosone.web.fc2. com/SennkinnYokuhouHanntai.pdf.

Shan'e yinguo jing 善惡因果經 [Sūtra on Causes and Effects]. 1 juan.

Translator unknown. T no. 2881, vol. 85 .

Shengjiani fennu jin'gang tongzi pusa chengjiu yigui jing 聖迦 柅忿怒金剛童子菩薩成就儀軌經 [Arya Kani Krodha Vajra Kumara Siddhi Upacara Sūtra]. 3 juan. Trans. by Bukong 不空 (Amoghavajra, 705-774) sometime between 756 and 774. T no. 1222b, vol. 21.

Shimen zhengtong 釋門正統 [Orthodox Record of Buddhism]. 8 juan.

By Zongjian 宗鑑 (d.u.), completed in 1237. ZZ no. 1513, vol. 75.

Tian qingwen jing 天請問經. [Devatā-sütra]. 1 juan. Trans. by

Xuanzang 玄牀 (602-664) in 648. T no. 592, vol. 15.

$X u$ Gaoseng zhuan 續高僧傳 [Continuation of the Histories of

Famous Monks]. 30 juan. Initially completed by Daoxuan 道宣 (596-667) in 645. T no. 2060, vol. 50.

Xuming jing 續命經 [Sūtra for Prolonging Lifespan]. 1 juan.

Translator unknown. T no. 2889, vol. 85.

Yan shouming jing 延壽命經 [Sutra for Prolonging Lifespan]. 1 juan.

Translator unknown. T no. 2888, vol. 85. Ryūkoku Library

Manuscript no. 2343.

Yulanpen jing 孟蘭盆經 [Ullambana-sūtra]. 1 juan. Trans. by Zhu

Fahu 笂法護 (239-316) sometime between 266 and 313. T no. 685, vol. 16. 
Zhaifa qingjing jing 齋法清淨經 [Sūtra on Eating Pure Food]. 1 juan. Translator unknown. T no. 2900, vol. 85. Ryūkoku University Library manuscript no. 739.

Zhongzhong za zhou jing 種種雜咒經 [Scripture Consisting of Various Kinds of Spells]. 1 juan. Trans. by She'najueduo 闍那崛 多 (Jñānagupta, 523-600). T no. 1337, vol. 21.

Zhoumei jing 呪魅經 [Sūtra of Incantation against Evil Spirits]. 1 juan. Translator unknown. T no. 2882, vol. 85 .

\section{Secondary Sources}

Barrett, T. H. “"Transcribed Printers” Colophons at Dunhuang as Evidence for Early Printing'. Journal of Inner Asian Art and Archaeology 6 (2011): 149-53.

Bibliothèque nationale (France), Département des manuscrits. Catalogue des manuscrits chinois de Touen-houang, fonds Pelliot chinois [Catalogue of Chinese Manuscripts from Dunhuang, Pelliot Chinese Fund]. Paris, Bibliothèque nationale, 1970-1990. Chen Juxia 陳菊霞. Dunbuang Zhai shi yanjiu 敦煌翟氏研究 [Study on the Zhai Family of Dunhuang]. Beijing: Minzu chubanshe 民 族出版社, 2012.

Ciyi 慈怡 et. al, eds. Foguang da cidian 佛光大辭典 [Great Dictionary of Foguang]. 8 vols. Gaoxiong: Foguang chubanshe 佛光出版社, 1988.

Duan Wenjie 段文傑, and Shi Pingting 施娉婷, eds. Gansu cang Dunbuang wenxian 甘肅藏敦煌文獻 [Dunhuang manuscripts stored in Gansu]. 6 vols. Lanzhou: Gansu renmin chubanshe 甘 肅人民出版社, 1999.

Dunhuang yanjiuyuan 敦煌研究院, comp. Dunbuang Mogao ku gongyang ren tiji 敦煌莫高窟供養人題記 [Donor Inscriptions left in Mogao Grottoes in Dunhuang]. Beijing: Wenwu chubanshe 文物出版社, 1986 .

Fang Guangchang 方廣锠, ed. Dunbuang Fojiao jinglu jijiao 敦煌 佛教經錄輯校 [Collated Collection of records of Dunhuang Buddhist Texts]. 2 vols. Dunhuang wenxian fenlei lujiao congkan 敦煌文獻分類錄校叢刊 [Series of Categorized Dunhuang Manuscripts, Transcribed and Collated]. Nanjing: Jiangsu guji 
chubanshe 江蘇古籍出版社, 1997.

. 'Dunhuang siyuan suo cang dazang jing gaimao' 敦煌寺 院所藏大藏經概貌 [The General Appearance of the Tripitaka Stored in the Temples and Monasteries of Dunhuang]. Zangwai Fojiao wenxian 藏外佛教文獻 [Extra-canonical Buddhist Texts] 8 (2003): 372-401. Accessed February 21, 2018. http://www. kanripo.org/text/KR6v0090/001.

_. 'Dunhuang wenxian zhong de Jingang jing ji qi zhushu' 敦 煌文獻中的《金剛經》及其注疏 [The Vajracheedika as Found Among the Dunhuang Writings and its Commentaries].

Accessed July 25, 2018. http://big5.xuefo.net/nr/ article31/311984.html.

, ed. Zangwai Fojiao wenxian 藏外佛教文獻 [Extra-canonical Buddhist Texts]. First series, vols. 1-10. Beijing: Zhongguo renmin chubanshe 中國人民出版社. 1995-2011.

, ed. Fojiao wenxian yanjiu 佛教文獻研究 [Studies in Buddhist Texts], 2 vols. Guilin: Guangxi Shifan daxue Chubanshe 廣西師 範大學, 2016.

. Zhongguo xieben Dazang jing yanjiu 中國寫本大藏經研究 [A Study of Chinese Manuscript Versions of the Tripitaka]. Shanghai: Shanghai guji chubanshe 上海古籍出版社, 2006. Giles, Lionel. Descriptive Catalogue of the Chinese Manuscripts from Tunbuang in the British Museum. London: The British Museum, 1957.

Huang Qijiang 黃啟江. 'Lun Songdai shiren de shouxie fojing' 論 宋代士人的手寫佛經 [A Discussion of Gentlemen’s Copying Buddhist Scriptures by Hand]. Jiuzhou xuekan 九州學林 [Chinese Culture Quarterly] 4.4(2006): 60-102.

Ji Xianlin 季羡林, ed. Dunbuang da cidian 敦煌學大辭典 [Great Dictionary of Dunhuangology]. Shanghai: Shanghai cishu chubanshe 上海辭書出版社, 1998.

Kawamura Kōshō 河村孝照 et. al, eds. Dai Nihōn zōkuzōkyō大日本 續藏經 [Supplement to the Buddhist Canon of Great Japan].90 vols. Tokyo: Kokusho Kangyōkai 國書刊行會, 1980-1988.

Lin Shitian 林世田, and Shen Guomei 申國美, eds. Dunbuang Mizong wenxian jicheng 敦煌密宗文獻集成 [Collection of Dunhuang Esoteric Manuscripts]. 3 vols. Zhongguo Foxue 
wenxian congkan 中國佛學文獻叢刊 [Series of Chinese Buddhist Manuscripts]. Beijing: Quanguo tushuguan wenxian suowei fuzhi zhongxin 全國圖書館文獻縮微複製中心, 2000.

Liu Difan 劉滌凡. 'Dunhuang xiejuan Zhongtu zaojing de jiushu sixiang tiyao: Yi Dazheng zang di 85 ce weili’ 敦煌寫卷中土造 經的救贖思想提要——以《正藏》第 85 冊為例 [The Essential Ideas behind Salvation as found in the Apocryphal Scriptures among the Dunhuang Manuscripts: With the Taishō Tripitaka Vol. 85 as an Example]. Zhonghua foxue xuebao 中華佛學學報 [Chung-Hwa Buddhist Journal] 14 (2001): 231-66.

Liu Guozhan 劉國展, and Li Guiying 李桂英. 'Tianjin Yishu bowuguan suocang Dunhuang juanzi ji shehui wenshu mulu' 天津藝術博物館所藏敦煌卷子及社會文書目錄 [Catalogue of the Inherited Rolls and Documents of Society from Dunhuang preserved in the Art Museum of Tianjin]. Dunbuang yanjiu 敦煌 研究 [Dunhuang Research] 2 (1987): 74-95.

Ma De 馬德. 'Dunhuang juanhua tiji jilu' 敦煌絹畫題記輯錄 [A Compilation of the Inscriptions on the Silk Paintings from Dunhuang]. Dunhuang xue jikan 敦煌學輯刊 [Journal of Dunhuang Studies] 1 (1996): 136-47.

Mollier, Christine. Buddhism and Taoism Face to Face: Scripture, Ritual, and Iconographic Exchange in Medieval China. Honolulu: University of Hawai'i Press, 2008.

Ning Qiang. Art, Religion and Politics in Medieval China: The Dunbuang Cave of the Zhai Family. Honolulu: University of Hawai'i Press, 2004.

Rong Xinjiang 榮新江. Eighteen Lectures on Dunbuang. Translated by Imre Galambos. Leiden: Brill, 2013.

- Guiyijun shi yanjiu 歸義軍史研究 [A Study of the History of the Guiyijun]. Shanghai: Shanghai guji chubanshe 上海古籍出版 社, 1996.

Soymié, Michel. 'Les donateurs dans les peintures de Dunhuang' [Donors of Dunhuang Paintings]. Cabiers d'Extrême-Asie [East Asian Journal] 11 (1999-2000): 1-24.

Sørensen, Henrik H. 'Donors and Esoteric Buddhism in Dunhuang during the Reign of the Guiyijun'. In Establishing of Buddhist Nodes in Eastern Central Asia 6th to 14th Century, Part I, edited 
by Carmen Meinert and Henrik H. Sørensen, 91-122. Leiden: Brill, 2019.

. 'Donors and Image at Dunhuang: A Case Study of OA1919, 0101,0.54.' BuddhistRoad Paper 4.1 (2019): 3-25.

. 'The Life and Times of Daozhen, a Samgha Leader and Monk-Official in Dunhuang during the 10th Century'. BuddhistRoad Paper 5.3 (2020): 3-32.

_ 'The Meeting of Daoist and Buddhist Spatial Imagination: The Construction of the Netherworld in Medieval China'. In Locating Religions: Contact, Diversity and Translocality, edited by Reinhold F. Glei and Nicholas Jaspers, 234-92. Leiden: Brill, 2017.

Takakusu Junjirō 高楠順次郎, and Watanabe Kaigyoku 渡邊海旭, eds. Taishō shinshū daizōkyō 大正新脩大藏經 [Buddhist Canon Compiled during the Taishō Era (1912-1926)]. 100 vols. Tokyo: Taishō issaikyō kankōkai 大正一切經刊行會, 1924-1932.

Tao Qiuying 陶秋英, and Jiang Liangfu 姜亮夫, eds. Dunbuang suijin 敦煌碎金 [Fragmented golds from Dunhuang]. Hangzhou: Zhejiang guji chubanshe 浙江古籍出版社, 1992.

Teiser, Stephen F. 'Ornamenting the Departed: Notes on the Language of Chinese Buddhist Ritual Texts'. Asia Major 22.1 (2009): 201-37.

- The Scripture of the Ten Kings and the Making of Purgatory in Medieval Chinese Buddhism. Studies in East Asian Buddhism. Honolulu: University of Hawai'i Press, 1994.

Wang Sanqing 王三慶. Dunbuang wenxian tiji biannian jiqi fenxi yanjiu 敦煌文獻題記編年及其分析研究 (3/3) [An Analysis and Study of the Colophons in the Dunhuang Written Material Collated According to Yearly Events]. Taibei: National Cheng Kung University, Department of Chinese Literature, 2004. Accessed October 18, 2019. http://ir.lib.ncku.edu.tw/ bitstream/987654321/139999/1/敦煌文獻題記編年及其分析研 究\%28III\%29.pdf.

Wang Youkui 王友奎. 'Dunhuang xieben Zhoumei jing yanjiu' 敦 煌寫本《咒魅經》研究 [A Study on Dunhuang Manuscripts Zhoumei-jing]. Dunbuang yanjiu 敦煌研究 [Dunhuang Research] 2(2012): 97-109. 
Whitfield, Roderick, and Anne Farrer. Caves of the Thousand Buddhas: Chinese Art from the Silk Road. London: British Museum Publications, 1990.

Zheng Binglin 鄭炳林. 'Wan Tang Wudai Dunhuang diqu Dabanruo jing xinyang yu difang zhengquan de guanxi’ 晚唐五代敦煌地區 《大般若經》信仰與地方政權的關係 [The Relationship between Mahāprajñapramitā-Sütra Belief and the Local Government in Dunhuang Area during the late Tang and Five Dynasties]. Pumen xuebao 普門學報 [Universal Gate Buddhist Journal] 34 (2006): 1-19.

Zhongguo Fojiao xiehui 中國佛教協會, comp. Fangshan Yunju si shijing 房山雲居寺石經 [Stone Scriptures at Yunju Temple on Mount Fang]. Beijing: Wenwu chubanshe 文物出版社, 1978. 